\title{
Literature Review: On Crustacean and Monogeneans of Commonly Catched Fish Species in Ethiopia
}

\author{
Kasse GE* \\ Gondar University, Ethiopia
}

*Corresponding author: Gashaw Enbiyale Kasse, Gondar University, Ethiopia, Tel: +251921576312; Email: enbiyalegashaw@gmail.com

\section{Mini Review \\ Volume 2 Issue 4}

Received Date: June 15, 2019

Published Date: July 01, 2019

DOI: $10.23880 /$ izab-16000161

\section{Abstract}

The objective of this study is to review crustacean and monogenean parasites of the fish species. The major diseases associated with fish are parasites, bacteria, viruses and toxic algae that reduces fish production by affecting the normal physiology of fish and if left uncontrolled, it can results in mass mortalities or in some cases, can be serve as source of infection for human and other vertebrates that consumed fish. External protozoa, crustacean and monogenetic trematodes of freshwater fish could be considered as the most prevalent causes of diseases affecting skin and gills causing gill inflammation and distortion of normal anatomy which impairing their respiratory foundation. Freshwater fish infested with skin-inhabiting flukes become lethargic, swim near the surface, and seek the sides of the pond and their appetite windless. There are several treatment options. Drugs or chemicals placed in the water are commonly referred to as "bath" treatments. Drugs delivered orally are generally mixed in the food, and are meant to deliver systemic effects. Maintain a good culture environment and prevent the deterioration of water environment; and use hygienic and nutritious fish feed to boost resistance of the fish stock and to minimize the chance of introducing pathogens into the water body.

Keywords: Fish Parasite; Monogenean; Crustacean

\section{Introduction}

Ethiopia is endowed with many lakes and rivers comprising diverse aquatic ecosystems of great scientific interest and economic importance. The countries fish potential is estimated at $45,000-51,500$ tons per year, according to several sources. In 2008, fish catch was estimated at around 17,000 tons (accounting for about $1.7 \%$ of the regional volumes), the bulk of which $(74 \%)$ originating from the six main lakes (Tana, Ziway, Langano, Hawassa, Abaya and Chamo) and a further $26 \%$ from the other water bodies. Thus, less than $38 \%$ of this potential is currently exploited, demonstrating considerable room for further expansion through proper management [1]. The construction of new reservoirs, under-exploited river fisheries and aquaculture are some of the development prospects to this end. Aquaculture is recognized as an alternative means of achieving food security and poverty reduction in the rural area, and is now considered an integral part of rural and agricultural development policies and strategies in Ethiopia. However, much remains to build institutional capacity in the areas of research, technology and training, which will requires external assistance [2]. A hundred local fish species have been identified, while the bulk of the production is made of Tilapia, Lates, Barbus, Bagrus, Clarias and Labeo 


\section{International Journal of Zoology and Animal Biology}

species. Approximately $80 \%$ of the catch is Tilapia, although Nile perch is caught in large quantities on Lakes Chamo and Abaya, as well as in major riverine fisheries. Most of the remainder of the lake catches consists of catfish and Barbus [3].

Lake Lugo (Hayke) provides a habitat to different fish species, water birds and aquatic organisms. The fish production potential of the Lugo Lake is estimated as 400 ton/year, and the off take rate is $83 \%$ as reported by FDRE (Federal Democratic Republic of Ethiopia) [4]. Fish in wild and aquaculture farms face a wide range of enemies including competitors, predators and parasites. The major diseases associated with fish are parasites, bacteria, viruses and toxic algae that reduces fish production by affecting the normal physiology of fish and if left uncontrolled, it can results in mass mortalities or in some cases, can be serve as source of infection for human and other vertebrates that consumed fish [5]. Parasites may induce a shift in fish species densities, size composition and affect commercially interesting stocks. This mainly depends on the vulnerability of species, habitats and seasonal factors. Because of their complex life cycles, parasites are indicative of many aspects of their hosts' biology, such as host diet, migration, recruitment, population distinctness and even phylogeny [6].

External protozoa, crustacean and monogenetic trematodes of freshwater fish could be considered as the most prevalent causes of diseases affecting skin and gills causing gill inflammation and distortion of normal anatomy which impairing their respiratory foundation. The crustaceans are the most diverse and ubiquitous. Among them, the copepods are dominant. They, jointly with the monogeneans, are the most species group of metazoan ectoparasites of fresh and marine fishes; in addition, they infect a wide range of marine invertebrates. Monogeneans (flukes) are a group of parasites best described as flatworms. Monogeneans are commonly found on the gills, skin or fins of fishes and lower aquatic invertebrates [5].

Ectoparasite infestations can cause severe skin damage such as abrasions and ulcerations on the body surface, hemorrhagic spots on the skin and eroded fins resulting in economic losses due to reduced growth, fecundity and increased morbidity and susceptibility to secondary infections. Production in Ethiopia as other developing countries is strengthened by the availability of extensive in land water systems made up of streams, rivers and lakes which support a large number of fish species, many of which are of economic importance [7].
To full develop and manage these diverse and rich fish resources in these inland water bodies, there is need for adequate knowledge of parasites that infect them with a view to adopting preventive and control measures to improve fish yield. Research commitments to the study of parasites of fresh water and marine fishes of the Ethiopian have been sporadic and inadequate considering the fish wealth of the countries [8]. This has been attributed to the lack of laboratory equipment, skilled man power, lack of public awareness on the fish production and health, library facilities.

\section{The Fish}

A fish is defined as an aquatic or marine animal with vertebrae. All fish have vertebra, except sharks and rays that have cartilage. Cartilage is more flexible than bone, but strong enough to support the body. A fish is any member of a paraphyletic group of organisms that consist of all gill-bearing aquatic craniate animals that lack limbs with digits. A typical fish uses gills to obtain oxygen from the water, while at the same time releasing carbon dioxide and metabolic wastes. It is ectothermic, or coldblooded, meaning that its body temperature fluctuates according to the water temperature [9]. Fish have almost the same organs as terrestrial animals; however, they also possess a swim bladder.

\section{Biology of Fish}

Anatomy of fish: The anatomy of fish is often shaped by the physical characteristics of water. The body of a fish is divided into a head, trunk and tail, although the divisions between the three are not always externally visible. The skeleton, which forms the support structure inside the fish, is either made of cartilage, in cartilaginous fish, or bone in bony fish. The main skeletal element is the vertebral column, composed of articulating vertebrae which are light weight yet strong. The main external features of the fish, the fins, are composed of either bony or soft spines called rays, which with the exception of the caudal fins have no direct connection with the spine. They are supported by the muscles which compose the main part of the trunk [10]. The heart has two chambers and pumps the blood through the respiratory surfaces of the gills and on round the body in a single circulatory loop. The eyes are adapted for seeing underwater and have only local vision. There is an inner ear but no external or middle ear. Low frequency vibrations are detected by the lateral line system of sense organs that run along the length of the sides of fish, and these respond to nearby movements and to changes in water pressure figure 1 [11]. 


\section{International Journal of Zoology and Animal Biology}

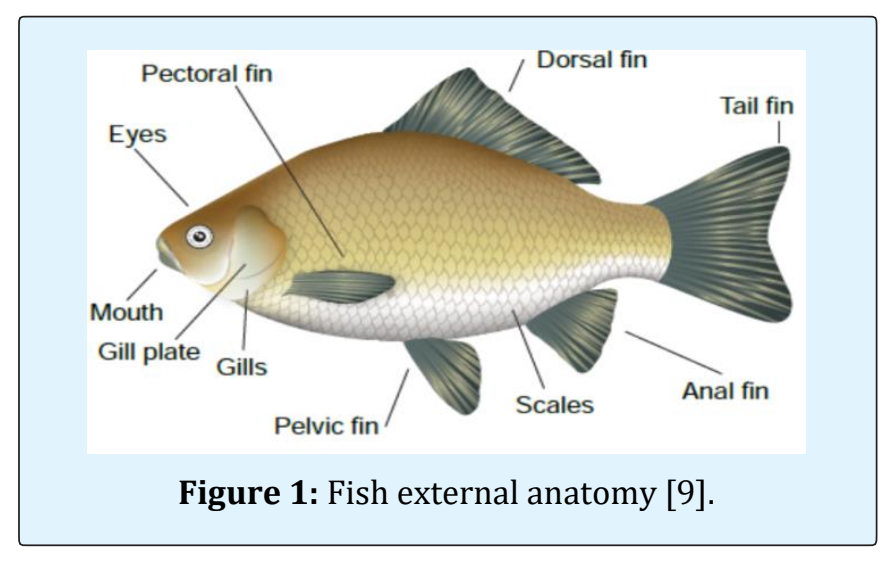

Physiology of fish: Fish breathe oxygen using their gills, which are located in each side of the head area. Gills consist of structures called filaments. Each filament contains a blood vessel network that provides a large surface area for the exchange of oxygen and carbon dioxide. Lymph volume in fish is four times larger than blood volume and capillaries have a high permeability to protein small changes in lymph formation can lead to large changes in blood composition sinus venous, atrium, ventricle and bulbous arteriosus [12]. Fish are poikilothermic or cold blooded and metabolic functions are dependent on the temperature of the surrounding water. Oxygen requirement to digest and absorb feed increases dramatically after feed intake [13]. Almost all fish lay eggs that develop outside of the mother's body; indeed, 97 percent of all known fish are oviparous. Fertilization of the eggs by the sperm, known as milt in fish biology, also occurs externally in most cases. The reproductive organs of fish include testes, which make sperm, and ovaries, which make eggs [14]. Some fish are hermaphrodites, having both testes and ovaries, either simultaneously, or at different phases in their life cycle. Fish will pass through the life stages of egg, larvae, fry, fingerling, grow-out (adult fish) and sexual maturity Figure 2.

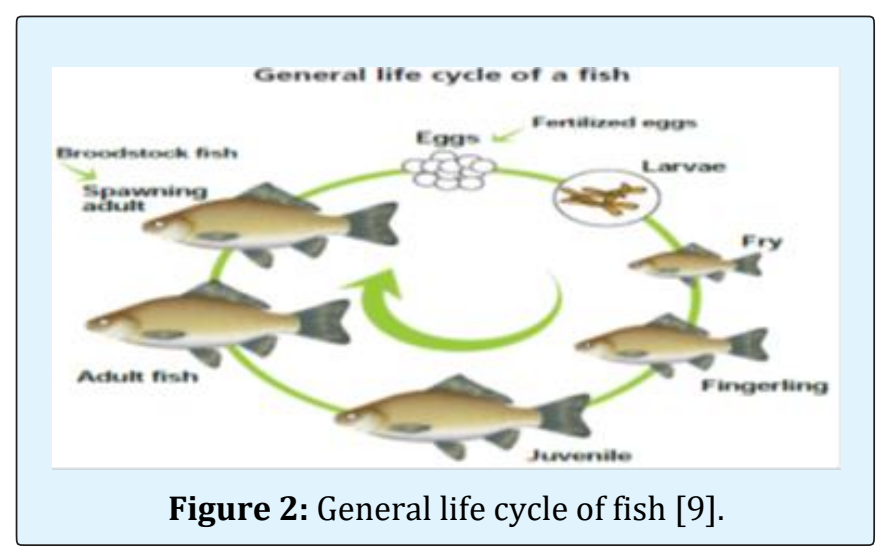

\section{Economic Important of Fish}

Fish demand is higher in production areas because of consumption stimulation by regular supply of good quality product at an affordable price vis-à-vis the price of meat. Consumer demand for fish is increases when supply is more regular on a year-round basis, shops are located closer to their homes, and fish prices are more affordable. Fish plays a vital role in domestic trade as well as in import and export market. Sustainable fisheries management is crucial to food security, poverty alleviation and economic growth. Fisheries are thus acknowledged as an important strategy in the drive for poverty reduction [15].

In 2010 Ethiopia realized about USD 14000000 from its capture fishery while a total of 40000 livelihoods were positively impacted upon by the fishery sector in the same year. Ethiopia's fishery sector contribution to the Gross Domestic Product (GDP) is 0.02 percent. The Ethiopian cross-border fish trade is currently not properly documented. The country imports significant amounts of fish from neighboring countries though some of these imports end up being exported to Sudan through the porous border with neighboring South Sudan. The per capita fish supply is around $200 \mathrm{~g}$, significantly below the mean $2.6 \mathrm{~kg}$ per capita per year for the East African subregion [1]. Considerable work force is employed, both directly and indirectly, by capture fisheries which also help in sustaining local communities. The rural areas of Ethiopia where substantial fishing takes place benefit from the economic activities of the fishers and their related operations. This is especially so around the Great Rift Valley and areas surrounding the lakes, reservoirs, rivers and other small water bodies with major fishing activities. In those areas, much more than in the urban and peri-urban centers, fisheries are increasingly recognized as an alternative means of addressing the problems of food security and poverty, consistently with the rural development objectives of the sector [3].

\section{External Parasitic Diseases of Fish}

The major diseases associated with fish are parasites, bacteria, viruses and toxic algae that reduces fish production by affecting the normal physiology of fish and if left uncontrolled, it can results in mass mortalities or in some cases, can be serve as source of infection for human and other vertebrates that consumed fish [16]. Parasites may induce a shift in fish species densities, size composition and affect commercially interesting stocks. Parasites are typically divided into two groups: ectoparasites, which live on the outside of the host (including the gills, mouth, skin and fin surfaces), and

Kasse GE. Literature Review: On Crustacean and Monogeneans of Commonly Catched Fish Species in Ethiopia. Int J Zoo Animal Biol 2019, 2(4): 000161. 


\section{International Journal of Zoology and Animal Biology}

endoparasites, which live in the tissues, blood and/or organs (including the gastrointestinal tract). The most important external parasites of fish are protozoa, crustaceans and monogenic trematod.

Crustacean parasites: The Latin root, crustaceus, "having a crust or shell," really doesn't entirely narrow it down to crustaceans. They belong to the phylum Arthropoda, as do insects, arachnids, and many other groups; all arthropods have hard exoskeletons or shells, segmented bodies, and jointed limbs. The crustaceans are the most diverse and ubiquitous. There are three main groups of parasitic crustaceans affecting commercially important aquaculture species, most of which are external parasites: the Branchiura, Copepoda and Isopoda [17]. Among them, the copepods are dominant. They, jointly with the monogeneans, are the most speciese group of metazoan ectoparasites of fresh water and marine fishes; in addition, they infect a wide range of marine invertebrates. Thousands of species are already known, but many potential host groups have not been examined, and for this reason even approximate estimates of species numbers are impossible. Many copepods have great economic importance as agents of disease in wild and aquacultures fish populations [18].

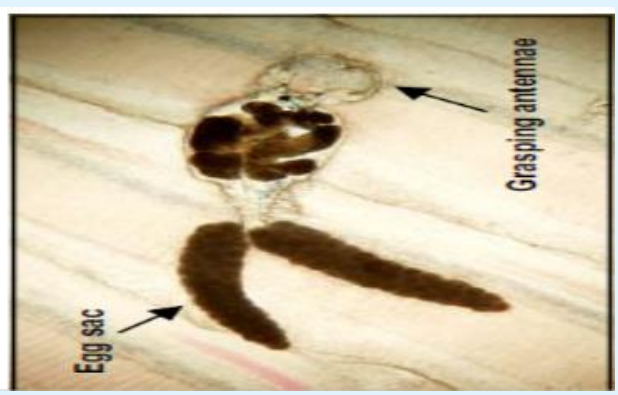

Figure 3: Body plans in the Copepoda [19]

a. Copepods (Sea Louse, Fish Maggot, Anchor Worm): Copepods have been parasitic on fishes at least since the Lower Cretaceous, about 110 to 120 million years ago. Nearly 30 families of copepods contain parasites that utilize fishes as hosts Crustacean parasites 125 and most are found exclusively on fishes [19]. The body form of fish parasites varies from cyclopiform through to highly metamorphic (rather amorphous bodies that lack expressed segmentation and either have reduced limbs or may lack limbs altogether).

b. Life cycles of copepods: The basic life cycle of copepods comprises two phases, Nauplius and copepodid. The egg typically hatches into a Nauplius larva defined by its small, unsegmented body and the possession of only three pairs of functional appendages, antennules, antennae and mandibles. There is a maximum of six Nauplius stages (designated NI-NVI) and all six are retained in most free-living copepods and in some parasites. Nauplius may be planktotrophic, feeding on other planktonic organisms, or lecithotrophic, relying on yolk stores for nutrients. Parasitic copepods typically have lecithotrophic Nauplius characterized by reduced station on the three limb pairs and by the absence of the so-called Nauplius feeding process on the coxa of the antenna [20]. The final Nauplius stage, primitively NVI, undergoes a metamorphic moult to the first copepodid, which has a segmented body, a full adult set of cephalic appendages and the first and second swimming legs. In free-living copepods there is a maximum of five copepodid stages (designated $\mathrm{CoI}-\mathrm{CoV}$ ) and one body somite is added at each moult through this phase. In both sexes the fifth copepodid stage moults into the adult. This is a definitive or final moult and the female becomes sexually receptive on moulting. Mating takes place soon after the female becomes sexually receptive and adult males may engage in pre-copulatory mate guarding, holding pre-adult females until the final moult [21].

c. Modifications of the copepodid phase: The first copepodid is relatively uniform in structure and is characterized by the presence of two functional pairs of biramous swimming legs, each with one-segmented rami. In general, the copepodid phase provides a gradual transition from the copepodid body form, which is common to all podopleans, to adult morphology, however transformed. In more derived families successive copepodid stages show increasing levels of modification in body form and limb structure, as compared to their free-living relatives [22]. In almost all copepod parasites the first copepodid is a free-swimming stage, the few exceptions include the monstrilloids and the brittle star parasite Parachordeumium amphiurae, which hatches directly as an infective second copepodid, having passed through the first within the egg. The basic copepodid phase, as primitively retained in siphonostomatoids (e.g. Cancerilla), comprises five stages plus the adult. The presence of pre-adults, as true moult stages, is a feature of many fish parasites [20]. Either one pre-adult (e.g. in Caligus clemensi) or two pre-adult stages (e.g. in Lepeophtheirus salmonis) may be interpolated into the basic life cycle, and represent an addition to the ancestral copepod life cycle.

d. Two-host life cycle: Some pennellids, such as Sarcotretes scopeli, retain a direct life cycle, while others have an unusual life cycle involving two 


\section{International Journal of Zoology and Animal Biology}

different hosts. After a brief planktonic phase, primitively comprising two Nauplius stages, the infective copepodid larva locates the first host. This may be a fish, as in the case of Lernaeocera or a gastropod mollusc, as in the case of Cardiodectes. Development through the attached chalimus stages to the sexually mature adults takes place on the gills or in the mantle cavity of the first host [23]. Mating takes place on the first host, after which the mated adult female, which is still basically cyclopiform in shape, leaves the first host and finds a second, usually a fish but occasionally a marine mammal. Once attached to the second host the female embeds and commences a profound metamorphosis involving considerable increase in body volume. The post-metamorphic female then produces egg strings while on the second host, using stored sperm to fertilize the eggs as they are extruded [24].

e. The infection process: The infective copepodid larva is typically small, in the order of $0.3 \mathrm{~mm}$ to $0.7 \mathrm{~mm}$ body length, but the oceans are enormous, potential hosts are patchily distributed and many of them are highly mobile. Clearly, overcoming the problems of locating a host and successfully infecting it are critical to the completion of the life cycle in parasitic copepods. Infection biology has been studied in a few fish parasites, especially sea lice [22]. Infective larvae in close proximity to fish hosts have been shown to respond to mechanical signals generated by the locomotory or respiratory motions of the potential host. The primary sensory interface between the copepodid and its environment is the paired antennules and their array of chemosensory, mechanosensory and bimodal setation elements [14].

f. Effects on hosts: Parasitic copepods damage their hosts directly by their attachment mechanisms and by their feeding activities. Attachment by means of clawed limbs is typical for ectoparasites and penetration of the skin by the claws cause's local lesions, the pathology of which varies according to site and other factors [25]. On the skin of fishes attachment can cause pressure necrosis and epidermal erosion and the host tissue responses can include swelling, hyperplasia, and proliferation of fibroblasts, fiber production and cellular infiltration. Any surface lesion may also render the host susceptible to secondary infections. Attachment to gill filaments typically results in hypertrophy of the gills and fusion of secondary lamellae, with consequent loss of respiratory surface area [23].

g. Most parasitic copepods feed by rasping at the surface of the host using their mandibles. Dislodged fragments of host tissue are taken directly into the mouth or oral tube and carried in to the gut for digestion (Ahne et al., 2002). Feeding activity produces surface lesions where the epidermis has been removed and, in cases of heavy or prolonged infestation, deeper lesions result, with damage to the dermis and blood vessels. Deeper lesions often result in hemorrhaging and can cause anemia.

Monogeneans (Skin fluke, Gill fluke, Eye fluke): Monogeneans (flukes) are a group of parasites best described as flatworms. Monogeneans are commonly found on the gills, skin or fins of fishes and lower aquatic invertebrates. A few may invade the rectal cavity, ureter, body cavity and even the blood vascular system. There are more than 100 families of monogeneans found on fishes of the world, in fresh and salt water, and at a variety of temperatures [13]. Most monogeneans are browsers, moving about the body surface and feeding on dermal (skin) mucus and gill debris. Monogeneans have a series of hooks that enable them to attach while feeding. Most species are host and site specific, requiring only one host to complete an entire life cycle [11]. In fact, some adult monogeneans will remain permanently attached to a single site on the host. Morbidity and mortality epidemics in cultured fish caused by excessive parasite loads are associated with crowding, inadequate sanitation and deterioration of water quality [26]. Although monogeneans are commonly found on wild fish, they are rarely a direct cause of disease or death in free-ranging populations [27]. Dactaylogyrus is usually attached to the gill of freshwater fish. It reproduces by laying eggs, which are often resistant to chemical treatment, therefore weekly treatment over a period of 3 to 4 weeks is recommended. Gyrodactylus is usually found on the skin and fins of freshwater fish and produces live young, so one treatment may be adequate to control an infestation. Benedeniella is a large monogenea that can cause chronic problems in marine systems and is difficult to eliminate from a system once established.

a) Transmission: Transmission of monogenean flukes from fish to fish is primarily by direct contact. Monogeneans tend to have direct life cycles, which mean that no intermediate host is required for the parasite to reproduce [28]. Adults are hermaphroditic, which means that each organism has both male and female reproductive structures. Oviparous monogenes (i.e., Dactylogyridae) release eggs into the water column that hatch and mature prior to seeking a new host. Viviparous monogeneas (i.e., Gyrodactylidae) release live larvae that are immediately able to attach to the same host as the parent or be carried by the water to another host [29]. The direct life cycle can contribute to population explosions in aquaculture 


\section{International Journal of Zoology and Animal Biology}

systems, resulting in clinical disease.

b) Clinical Signs and Effects: Freshwater fish infested with skin-inhabiting flukes become lethargic, swim near the surface, seek the sides of the pond and their appetite dwindles. They may be seen rubbing the bottom or sides of the holding facility (flashing) [30]. The skin, where the flukes are attached, shows areas of scale loss and may ooze a pinkish serous fluid. Heavy gill infestations result in respiratory disease. Gills may be swollen and pale, respiration rate may be increased, and fish will be less tolerant of low oxygen conditions. "Piping," gulping air at the water surface, may be observed in fish with severe respiratory distress. Large numbers of monogeneans on either the skin or gills may result in significant damage and mortality. Secondary infection by bacteria and fungus is common on tissue that has been damaged by monogeneans [31].

External parasites treatments: When it comes to treatments, there are several options. Drugs or chemicals placed in the water are commonly referred to as "bath" treatments. Drugs delivered orally are generally mixed in the food, and are meant to deliver systemic effects. Injections may be utilized in cases where small numbers of fish are involved. Bath treatments are the most variable, in that a specific concentration of the chemical is placed in the water for a specific length of time [32]. As a rule, lower concentrations are used for longer periods of time, and vice versa. Salt, plain old sodium chloride, is often overlooked as the number one best chemical to manage fish health. For most purposes, simple, un-iodized table salt is adequate, although there is nothing wrong with using aquarium salt specifically sold for that purpose, such as sea salt, solar salt and salt sold for consumption by livestock.

There are many common ways to use salt in freshwater tropical fish medicine. As an aid to osmoregulation, salt may be added in a concentration of $0.5-1.0 \%$ (or 5-10 parts per million-ppm). This concentration is safe for several hours and up to several days. At this concentration, control of protozoan parasites can be achieved. Higher concentrations of salt for shorter periods of time may be used to eliminate protozoa [33]. Different parasites often need different treatments. This can be important when more than one species is involved. While general anti-parasite treatments are effective with most parasites, they do not treat all parasites. Sometimes, for various reasons such as under-dosing, water chemistry, organic pollution or green water, treatments do not work [34]. Treatment can be dependent on the following: Species involved, whether treatment takes place in display tank or back-up tank, Volume of tank (some drugs may be too expensive), Value of display organisms (if easily replaced it may be simpler to chlorox the whole tank and start all over), How dangerous the organism is (if one has parasitic din flagellates, the tank is small, and the display organisms are common it is best to kill everything before the parasite spreads) [35]. Fresh water dips for saltwater fish and saltwater dips for fresh water fish will dislodge some external parasites. Length of dips will vary per species; usually three-five minute dips will suffice, remove fish if they go into extreme distress.

External Parasites Prevention: Avoid purchasing or adding fishes to new established tank which exhibits the following symptoms $[22,24,36]$. Unusual swimming behavior e.g. tailspin, rapid or jerky movement, Signs of injuries to fins and body. E.g. bleeding, ulcers, skin or fin tear, not eating. A healthy fish will devour any food gladly, Eyes blurry, Popeye or cloudiness. Pay attention to the fishes for at least a few minutes a day and observe the behavior [36-46]. Stressed fishes may exhibit certain unusual behavior: Not eating, always hiding, being bullied by other tank mates regularly, Coming up to the surface to breath regularly, could be a sign of an over-crowded tank or insufficient dissolved oxygen in the water. Ensure the water condition is kept to the ideal level. Check for presence of ammonia and variation in $\mathrm{pH}$ (test kits are easily available) at least once a month. Practice regular fresh water changing, make sure the temperature and $\mathrm{pH}$ level is similar and not to more than $50 \%$ of the water at one. Generally we should: maintain a good culture environment and prevent the deterioration of water environment; and use hygienic and nutritious fish feed to boost resistance of the fish stock and to minimize the chance of introducing pathogens to the water body.

\section{Conclusion and Recommendations}

Fish has become an important resource in Ethiopia to meet the food and nutrition security needs of a rapidly expanding human population. Most of the chronic diseases of fish are caused by external parasites. From this study, it might be concluded that the parasite Dactaylogyrus spp is the most important species of monogenea that can be used as bio indicators of the environmental pollution in the Lake Lugo, and infected Carp and Tilapia fish which are the most distributed fish's species in the Lake of Lake Lugo [47-52]. The finding have shown that the gill of fish have been found to be harboring of a large group of external parasite that may be resident and transit parasite and some of parasite isolates including Lerneaspp and Dactaylogayrus spp cause mortalities when the fish became under stress [5359]. So that aquaculture and fish farming conditions 


\section{International Journal of Zoology and Animal Biology}

should be improved in a way that controls the spread of disease, which negatively impacts on the development of the sector.

Based on the conclusion the following recommendations were forward:

- Capacity building in fish parasitology and pathology by establishing network with international institutes experienced in the field. The effects of parasites on fish hosts in the wild may be difficult to isolate and quantify. However, studies of fish in captivity or under culture conditions have provided much information about the effects of parasites on fish survival.

- Care should be taken while introducing the new fish into the population

- Isolation of Dactaylogyrus spp from fish indicates pollution of the Lake so that sanitary measures around the Lake should be taken by the concerned authorities and organization,

- Further detained studies should be conducted on the epidemiology and ecology external parasite especially crustacean parasite because it may serve as intermediate host for zoonotic diseases e,g. Diphlobotrium spp,

- Husbandry practice (water quality assessment and feed and feed delivery management), health management (vaccination and treatment) and anti-predatory strategy

- Awareness creationis needed for fishermen on the new products like smoking \& drying.

\section{References}

1. FAO (2012) Review of the fisheries and aquaculture sector: Ethiopia. FAO: corporate document repository.

2. FAO (2003) Fishery country profile: Food and Agriculture Organization of the United Nations FID/CP/ETH.

3. Dereje TK (2014) Spatial and temporal distributions and some biological aspects of commercially important fish species of Lake Tana, Ethiopia. J Coastal Life Med 2(8): 589-595.

4. FDRE (Federal Democratic Republic of Ethiopia) (2003) Information on fisheries management in the Federal Democratic Republic of Ethiopia.

5. Paperna I (1980) Parasites, infections and diseases of fish in Africa. CIFA Tech Paper No 7 FAO Publication, pp: 216.
6. Bush AO, Fernández JC, Esch GW, Seed JR (2001) Parasitism: The Diversity and Ecology of Animal Parasites. Cambridge University Press, Cambridge.

7. Raugue CA, Viozzi GP, Semenas LG (2003) Component Population Study of Acanthocephalus tumescens (Acanthocephala) in Fishes from Lake Moreno, Argentina. Folia Parasitologica 50: 72-78.

8. Roberts JR, Somerville A (1982) Diseases of Tilapia In: Pullin RS and Lowe, McConnell RH (Eds.), The Biology and culture of Tilapias. ICLARM Conference Proceedings, 7 Manilla, Philiphines pp: 247-263.

9. Prosser C (1991) Ladd Comparative Animal Physiology, Environmental and Metabolic Animal Physiology $4^{\text {th }}$ edition pp: 552.

10. Bartholomew JL (2002) Salmonidceratomyxosis. In: AFS FHS (American Fisheries Society-Fish Health Section), FHS Blue Book.

11. Mwita C, Nkwengulila G (2004) Parasites of Clarias gariepinus (Burchell, 1822) (Pisces: Clariidae) from the Mwanza Gulf, Lake Victoria. Tanzania Journal of Science 30: 53-61.

12. John AM (2005) Management techniques for elasmobranch fisheries. FAO: Fisheries and Aquaculture Department.

13. Andrews C, Riley A (1982) Anthelminthic treatment of fish via stomach tube. Fisheries Management 13(2): 83-84.

14. Callahan HC, Noga EJ (2002) Tricaine dramatically reduces the ability to diagnose protozoan ectoparasite (Ichthyobodonecator) infections. Journal of Fish Diseases 25(7): 433-437.

15. Janko AM, Zeway (2014) Fisheries Resources Research Center, Ethiopia. Fish Production, Consumption and Management in Ethiopia. Research Journal of Agric \& Env Management 3(9): 460-466.

16. Anonymous (2006) OIE Manual of Diagnostic Tests for Aquatic Animals, $5^{\text {th }}$ (Edn.), World Organization for Animal Health (OIE), Paris.

17. Johnson SC, Treasurer JW, Bravo S, Nagasawa K, Kabata ZA (2004) Review of the impact of parasitic copepods on marine aquaculture, Zoological Studies 43(2): 229-243. 


\section{International Journal of Zoology and Animal Biology}

18. Bychowsky BE (1981) Monogenetic trematodes, their classification and phylogeny, pp: 509.

19. Ahne W, Bjorklund HV, Essbauer S, Fijan N, Kurath G (2002) Spring viremia of carp (SVC). Diseases of Aquatic Organisms 52(3): 261-272.

20. Andrew TG, Huchzermeyer KD, Mbeha BC, Nengu SM (2008) Epizootic ulcerative syndrome affecting fi sh in the Zambezi river system in Southern Africa. Veterinary Record 163(21): 629-631.

21. Arthur JR, Bondad Reantaso MG, Subasinghe RP (2008) Procedures for the quarantine of live aquatic animals: A manual. FAO: Fisheries Technical Paper No. 502. Food and Agriculture Organization of the United Nations, Rome pp: 74.

22. Bullock GL (2003) Enteric redmouth disease. In: AFS FHS (American Fisheries Society - Fish Health Section), FHS Blue Book: Suggested Procedures for the Detection and Identification of Certain Finfish and Shellfish Pathogens, $2^{\text {nd }}$ (Edn.), AFS - FHS, Bethesda.

23. Erickson HS (2003) Information Sources on Fish Welfare: 1970-2003. Animal Welfare Information Center, US pp: 13.

24. Baya AM, Toranzo AE, Lupiani B, Santos Y, Hetrick FM (1992) Serratia marcescens: A potential pathogen for fish. Journal of Fish Diseases 15(1): 15-26.

25. AFS FHS (2007) FHS Blue Book: Suggested Procedures for the Detection and Identification of Certain Fin fish and Shell fish Pathogens, $6^{\text {th }}$ (Edn.), Fish Health Section, American Fisheries Society, American Fisheries Society-Fish Health Section, Bethesda, MD.

26. Allumma MI, Idowu RT (2011) Prevalence of Gills helminth of Clarias gariepinus in Baga side of Lake Chad. J ApplSci Environ Manage 15(1): 47-50.

27. Barber I, Hoare D, Krause J (2000) Effects of Parasites on Fish Behaviour: A Review and Evolutionary Perspective. Reviews in Fish Biology and Fisheries 10(2): 131-165.

28. Chen SC, Tung MC, Chen SP, Tsai JF, Wang PC, et al. (1994) Systematic granulomas caused by a Rickettsia-like organism in Nile tilapia, Oreochromisniloticus (L) from southern Taiwan. J Fish Diseas 17(6): 591-599.
29. Palm HW (2011) Fish Parasites as Biological Indicators in a Changing World: Can We Monitor Environmental Im- pact and Climate Change? In: Mehlhorn H, et al. (Eds.), Progress in Parasitology, Parasitology Research Monographs, Springer Verlag, Chapter pp: 223-250.

30. Anderson DP, Barney PJ (1991) The role of the diagnostic laboratory in fish disease control. Annual Review of Fish Diseases 1: 41-62.

31. Smith JW (1999) The distribution of one monogenean and two copepod parasites on whiting, Merlangius merlangus L. caught in British waters. Norw J Zool 17: 57-63.

32. Mora JDW, Arthur JR, Burt MDB (1996) Parasites of Sharp-Beaked Redfishes (Sebastes fasciatus and Sebastes mentella) Collected from the Gulf of St. Lawrence, Canada. Canadian Journal of Aquatic Sciences 53(8): 1821-1826.

33. Al Samman A, Molnár K, Székely C (2006) Infection of cultured and freshwater fishes with monogeneans in Syria. Bulletin of the European Association of fish Pathologists 26(4): 170.

34. Margolis L, Esch GW, Holmes JC, Kuris AM, Schad GA (1982) The Use of Ecological Terms in Parasitology. Journal of Parasitology 68(1): 131-133.

35. Khalil LF, Polling K (1997) Checklist of the Helminth Parasites of African Freshwater Fishes. University of the North Department of Zoology, Republic of South Africa pp: 184.

36. Anonymous (2002) Fish Mortality Management. Alabama Aquaculture Best Management Practice (BMP), BMP No. 13, Auburn University and USDA/Natural Resources Conservation Service, pp: 3.

37. Abd EL Gawad RA (2004) Studies on Ectoparasites of Fresh Water Fish. Unpublished M. V. Sc. Faculty of Veterinary Medicine, Zagazig University.

38. Ahne W, Jaing Y, Thomsen I (1987) A new virus isolated from cultured grass carp Ctenopharyngodonidella. Diseases of Aquatic Organisms 3: 181-185.

39. Akinsanya B, Hassan AA, Adeogun AO (2008) Gastrointestinal helminth parasites of the fish Synodontis Clarias (Siluriformes: Mochokidae) from 


\section{International Journal of Zoology and Animal Biology}

Lekkilagoon, Lagos, Nigeria. Int J Trop Biol 56(4): 2021-2026.

40. Austin B, Austin DA (1993) Bacterial Fish Pathogens. Diseases in Farmed and Wild Fish 2nd (Edn.), Ellis Horwood, New York.

41. Basson L, Van As JG (1991) Trichodinids (Ciliophora: Peritrichia) from a Calanoid Copepod and Catfish from South Africa and Notes on Host Specificity. Systematic Parasitology 18(2): 147-158.

42. Hargis WJ, Oustinoff PC (1981) Moscow: Leningrad: Academy of Sciences, U.S.S.R. English translation by Hargis WJ and Oustinoff PC. Washington: American Institute of Biological Sciences.

43. Kebede E, Getachew T, Taylor WD, Zinabu GM (1992) Eutrophication of Lake Hayq in the Ethiopian Highlands J Plankton Res 14: 1473-1482.

44. Lacerda ACF, Takemoto RM, Lizama MAP, Pavanelli GC (2007) Parasitic copepods in the nasal fossae of five fish species (Characiformes) from the upper Paraná River floodplain, Paraná, Brazil. Acta Sci Biol Sci 29(4): 429-435.

45. Madanire Moyo G, Barson M (201) Diversity of Metazoan Parasites of the African catfish Clarias gariepinus Burchell, 1822) as Indicators of Pollution in a Subtropical African River System. Journal of Helminthology 84(2): 216-227.

46. Mamani M, Hamel, Van Damme PA (2014) Ectoparasites (Crustacea Branchiura) of Pseudoplatystoma fasciatum (surubí) and P. tigrinum (chuncuina) in Bolivian white-water floodplains. Ecologia en Bolivia 39(2): 9-20.

47. Matla MM, Mokgalong NM, Mashego SN (2010) Monogenea of the genus Dactylogyrus from cyprinids of the genera Barbus, Labeobarbus and Labeo in Lake Tzaneen, South Africa. Journal of the South African Veterinary Association 81: 181-182.

48. Mbokane EM, Luus Powell WJ, Matla MM, Theron J (2010) Three dactylogyrids (Dactylogyridae Bychow sky 1933: Monogenea) from selected cyprinid species of the Nwanedi- Luphephe Dams in the Limpopo Province, South Africa. Journal of the South African Veterinary Association 81: 186-187.
49. Mouton A, Basson L, Impson D (2001) Health status of ornamental freshwater fishes imported to South Africa: a pilot study. Aquarium Sciences and Conservation 3(4): 327-333.

50. Mwanja WW, Signa W, Eshete D (2011) FAO Subregional Office for Eastern Africa, Addis Ababa. Fisheries and Aquaculture in Eastern Africa pp: 1-30.

51. Nkwengulila G, Mwita C (2004) Spatial Distribution of Parasites along the Gut of the Catfish Clarias gariepinus (Burchell, 1822) (Clariidae) from the Mwanza Gulf, Lake Victoria. Tanzania Journal of Science 30: 64-69.

52. Paperna I (1996) Parasites, Infections and Diseases of fishes in Africa- an update. CIFA Technical Paper No. 31, Rome, FAO, pp: 220.

53. Piasecki W, Goodwin AE, Eiras JC, Nowak BF (2004) Importance of copepoda in freshwater aquaculture. Zoolog Studies 43(2): 193-205.

54. Polyanski Yu I (1961) Zoogeography of parasites of the USSSR marine fishes. In: Dogiel VA, et al. (Eds.), Parasitology of fishes Edinburgh and London: Oliver and Boyd pp: 230-246.

55. Price CE, McClellan S, Druckenmiller A, Jacobs LG (1969) The monogenean parasites of African fishes. X. Two additional Dactylogyrus species.

56. Reed PR (2005) Francis-Floyd and R. Klinger, Monogenean Parasites of Fish 1: 3-26.

57. Skelton PHA (2001) complete guide to the freshwater fishes of Southern Africa. $2^{\text {nd }}$ (Edn.), Struik Publishers, Cape Town, South Africa.

58. Tekin Özan S, Kir I, Barlas M (2008) Helminth parasites of common carp (Cyprinus carpio L, 1758) in Beyșehir Lake and population dynamics related to month and host size. Turkish Journal of Fisheries and Aqua tic Sciences 8: 201-205.

59. Thrusfield M (2005) Sampling In: Veterinary Epidemiology. $3^{\text {rd }}$ (Edn.), London: Black Well Science Ltd pp: 79-284. 